\title{
Assessment and Spatial Distribution Mapping of Criteria Pollutants
}

\author{
Kuldeep Kamboj • Sohil Sisodiya • \\ Anil K. Mathur $\cdot$ Ali Zare $\cdot$ Puneet Verma
}

Received: 21 November 2021 / Accepted: 26 January 2022 / Published online: 26 February 2022

(C) The Author(s) 2022

\begin{abstract}
This study aims to assess the urban air quality, and map $\mathrm{NO}_{2}, \mathrm{SO}_{2}$, and $\mathrm{PM}_{10}$ profiles using two widely spatial interpolation methods, ordinary kriging (OK) and inverse distance weighting (IDW) by estimating their concentrations at distinct nonmonitored locations. Assessment and mapping of air pollutants in this study help with policy formulation and decision-making. Kota, the industrial and educational hub of Rajasthan (India), has been selected to study air quality. Results showed that $\mathrm{PM}_{10}$ is continuously emerging as a foremost contributor to air quality index (AQI) each season. The concentrations of $\mathrm{NO}_{2}$ and $\mathrm{SO}_{2}$ in all seasons were well below the permissible level prescribed by the Central Pollution Control Board (CPCB). Interpolation techniques (OK and IDW) estimated the concentrations of $\mathrm{NO}_{2}, \mathrm{SO}_{2}$, and $\mathrm{PM}_{10}$ at three sites using air quality data from
\end{abstract}

K. Kamboj · S. Sisodiya · A. K. Mathur

Department of Civil Engineering, University Departments, Rajasthan Technical University (RTU), Kota 324010, Rajasthan, India

A. Zare

School of Engineering, Waurn Ponds Campus, Building KE 75 Pigdons Road, Waurn Ponds, Victoria 3216, Australia

P. Verma $(\bowtie)$

International Laboratory of Air Quality and Health, Queensland University of Technology (QUT), Brisbane, QLD 4001, Australia

e-mail: puneet.verma@ connect.qut.edu.au the year 2019. The interpolated air pollutant results for the specified region were compared with monitored air quality data in the same region. An excellent agreement has been observed by comparing monitored values, and the values predicted from IDW and OK.

Keywords $\mathrm{NO}_{2} \cdot \mathrm{SO}_{2} \cdot \mathrm{PM}_{10} \cdot \mathrm{AQI} \cdot \mathrm{NAAQS} \cdot$ Interpolation techniques

\section{Introduction}

The tropospheric air quality is greatly affected by numerous industrial and economical activities such as thermal power plants, vehicular traffic, and waste management. These activities alter the composition of ambient air and affect the atmosphere globally, regionally, and locally (Kuldeep et al. 2022). Various atmospheric studies suggested that anthropogenic sources have changed the composition of ambient air by less than $0.01 \%$. Nevertheless, this $0.01 \%$ change has a significant adverse effect on the climate of the earth (Region City PM2.5 Ranking \& World Air Quality 2020).

The presence of airborne substances resulting from natural and anthropogenic activities present in the atmosphere at concentrations significantly higher than their normal levels is termed air pollution (Pathakoti et al. 2021). It is responsible for several adverse effects on human beings and animals and harmful 
to materials, vegetation, and the environment (Othman et al. 2010). Air pollution is a concern to human health. About $92 \%$ of the world's population inhales toxic air (Region City PM2.5 Ranking \& World Air Quality 2019). In developing countries, approximately $98 \%$ of kids below 5 years breathe polluted air (Xu et al. 2019).

According to the World Air Quality Report 2019 (Region City PM2.5 Ranking \& World Air Quality 2019), 39 cities in India were in the top 100 most polluted cities in the world and 11 cities out of 15 most polluted cities in the Central and South Asia region. Most Indian cities suffer from an extremely high level of urban air pollution, particularly in the form of $\mathrm{CO}, \mathrm{SO}_{2}, \mathrm{NO}_{\mathrm{x}}$, and $\mathrm{PM}$. These pollutants are from different sources such as the transportation sector. For example, the diesel and petrol engine vehicles emit nitrogen oxides (NOx), carbon monoxide (CO), hydrocarbon (HC), sulphur dioxide $\left(\mathrm{SO}_{2}\right)$, particulate matter (PM), and volatile organic compounds (VOC's) which have substantial contribution in degrading urban air quality (Batterman et al. 2007; Bosco et al. 2005; Emami et al. 2018; Marć et al. 2016; Wu et al. 2011).

An understanding of the spatial distribution of $\mathrm{PM}_{10}, \mathrm{SO}_{2}$, and $\mathrm{NO}_{2}$ requires a rational approach to locate the possible sources of these pollutants in cities to avoid associated environmental problems linked to air quality. To improve the policy-related decisionmaking mechanism, many countries have been monitoring air quality (Alvarez-Mendoza et al. 2019). In India, air quality stations are established and monitored by Central Pollution Control Board (CPCB),
New Delhi, with National Ambient Air Quality Monitoring Series (NAAQMS) under National Air Monitoring Programme (NAMP). Table 1 shows the National Ambient Air Quality Standards (NAAQS) published by the CPCB in the Gazette of India. Table 1 shows the permissible weighted average concentrations for different habitat conditions such as residential, industrial, and ecologically sensitive areas. For an ambient air quality station, measurement methods should be in accordance with the methods indicated in Table 1.

The air quality index (AQI) used in India is presented in Table 2. An AQI can be described as an overall scheme that transforms weighted values of individual air pollution-associated factors $\left(\mathrm{NO}_{2}, \mathrm{SO}_{2}\right.$, $\mathrm{PM}_{10}$ ) into a single number or set of numbers.

The target criteria pollutants in this paper are $\mathrm{PM}_{10}, \mathrm{SO}_{2}$, and $\mathrm{NO}_{2}$ studied for Kota city of Rajasthan state in India. The objectives of this manuscript are (1) to evaluate and understand the air quality characteristics on the seasonal and annual basis; and (2) to evaluate interpolation accuracy of OK and IDW based upon observed data and the spatial distributions of the pollutants across the city.

\section{Methodology}

\subsection{Study Area and Site Characteristics}

Kota city, situated in Rajasthan, India, was selected to assess and map air quality with the help of monitored air quality data. Kota district is situated in South-East

Table 1 Pollutants, their permissible limits, and method of measurements prescribed by the CPCB

\begin{tabular}{|c|c|c|c|c|c|}
\hline \multirow[t]{2}{*}{ S. no } & \multirow{2}{*}{$\begin{array}{l}\text { Pollutant concen- } \\
\text { tration }\left(\mu \mathrm{g} / \mathrm{m}^{3}\right)\end{array}$} & \multirow{2}{*}{$\begin{array}{l}\text { Time- } \\
\text { weighted } \\
\text { average }\end{array}$} & \multicolumn{2}{|c|}{ Concentration in ambient air } & \multirow[t]{2}{*}{ Measurement methods } \\
\hline & & & $\begin{array}{l}\text { Residential, industrial, } \\
\text { rural, and other areas }\end{array}$ & $\begin{array}{l}\text { Ecologically } \\
\text { sensitive area }\end{array}$ & \\
\hline \multirow[t]{2}{*}{1} & \multirow[t]{2}{*}{$\mathrm{SO}_{2}$} & Annual* & 50 & 20 & \multirow{2}{*}{$\begin{array}{l}\text { - Ultraviolet fluorescence } \\
\text { - Improved West and Gaeke }\end{array}$} \\
\hline & & $24 \mathrm{~h}^{* *}$ & 80 & 80 & \\
\hline \multirow[t]{2}{*}{2} & \multirow[t]{2}{*}{$\mathrm{NO}_{2}$} & Annual* & 40 & 30 & \multirow{2}{*}{$\begin{array}{l}\text { - Chemiluminescence } \\
\text { - Modified Jacob and Hochheiser (Na-arsenite) }\end{array}$} \\
\hline & & $24 \mathrm{~h} * *$ & 80 & 80 & \\
\hline \multirow[t]{2}{*}{3} & \multirow[t]{2}{*}{$\mathrm{PM}_{10}$} & Annual* & 60 & 60 & \multirow{2}{*}{$\begin{array}{l}\text { - Beta attenuation } \\
\text { - Gravimetric } \\
\text { - Tapered element oscillating microbalance }\end{array}$} \\
\hline & & $24 \mathrm{~h} * *$ & 100 & 100 & \\
\hline
\end{tabular}

*Arithmetic average calculated annually from at least 104 analyses in a calendar year for a specified sampling location at regular intervals recorded for $24 \mathrm{~h}$ twice in the 7 days

**24 hourly monitored values of pollutants should comply with $98 \%$ of the period in a year 
Table 2 Indian air quality index with possible health effects

\begin{tabular}{|l|l|l|l|}
\hline $\begin{array}{l}\text { Color } \\
\text { Code }\end{array}$ & Category & AQI & Possible Health Impacts \\
\hline & Good & $0-50$ & Negligible impact \\
\hline & Satisfactory & $51-100$ & Sensitive people having minor breathing discomfort \\
\hline & Moderate & $101-200$ & Breathing discomfort, cardio-respiratory and heart diseases \\
\hline & Poor & $201-300$ & Prolonged exposure leads to breathing discomfort \\
\hline & Very Poor & $301-400$ & Prolonged exposure leads to respiratory illnesses \\
\hline & Severe & $401-500$ & Significantly affects those with existing diseases \\
\hline
\end{tabular}

of Rajasthan state, sharing its areal boundary by Bundi, Baran, Jhalawar, and Chittorgarh districts. The geographical area of Kota, which is $512 \mathrm{~km}^{2}$ (Forest Survey of India (2020)) cititaion of forest survey of India, is the 16th largest district by population as per the Census of India in 2011 (Indian Census 2011). The population of Kota was $1,001,694$, and it is expected to increase more than double at the end of this decade as per previous trends. Kota district consists of $60.3 \%$ urban and $39.7 \%$ rural population (Census of India). Kota city (urban) is located on the Chambal riverfront. It has a semi-arid climate with long summers starting from late March to June. The temperature reaches as high as $46{ }^{\circ} \mathrm{C}$ during peak summers and declines to $9{ }^{\circ} \mathrm{C}$ during winter (December and January).

Figure 1 indicates the locations of all stations used for the study across the city, and all sites lie within the urban boundaries. Kota is a major industrial as well as economic hub of Rajasthan. Several factors can affect the pollutant concentrations, such as traffic density, industrial hubs, and thermal power plants. These are important to be considered for ascertaining target locations across the city. The studies show that mixed land use patterns and higher traffic density can affect the population (Shukla et al. 2020). Large cities with proximity to major highways have huge dominance of road traffic, invariably causing air pollution. However, the pollutant levels often fluctuate due to the local environment or meteorological factors as well as traffic size, land use pattern, or building orientations (Abernethy et al. 2013; Farrell et al. 2015; Rivera et al. 2012). The key characteristics of target and monitoring locations are summarised in Tables 3 and 4.

The air pollutant concentration data from CPCB and RSPCB monitoring stations were collected for four different sites for 12 months. The highest concentration of $\mathrm{PM}_{10}$ was observed during January 2019 at Rajasthan Technical University, Kota, and the lowest at the Samcor Glass Limited in August 2019. $\mathrm{SO}_{2}$ and $\mathrm{NO}_{2}$ did not show significant fluctuations, with higher values in January 2019 and lowest during September 2019.

For seasonal breakdown, in a particular year, winter starts from November and stretches to February, followed by the summer season, which starts from March and continues until June. Monsoon with early showers starts in July and ends by October.

\subsection{Data Analysis}

The level of accuracy, availability of data, and computational/human facilities at disposal are the influential criteria in choosing a particular method. The present study utilises two methods of spatial interpolation, namely, ordinary kriging (stochastic method) and inverse distance weighing (deterministic method). Using $\mathrm{SO}_{2}, \mathrm{NO}_{2}$, and $\mathrm{PM}_{10}$ for spatial interpolation has two reasons. Firstly, they can be correlated over well-defined geographic regions and secondly, they are spatially variable over the topographic/geographic locations. For geospatial analysis, the base data was obtained from various sites used for NAAQS. These stations provide $1-\mathrm{h}, 8-\mathrm{h}$, and $24-\mathrm{h}$ averaged values of various pollutants along with other meteorological parameters such as wind direction, wind speed, and other air quality parameters as prescribed by the CPCB to define the air pollution level for the city.

To perform the spatial analysis of varying datasets amongst different pollutants, 'Geostatistical Analyst' in ArcGIS software was adopted. It is assisted with the development of a two-dimensional surface using monitored data by advanced statistical 
Fig. 1 Study area with monitoring stations

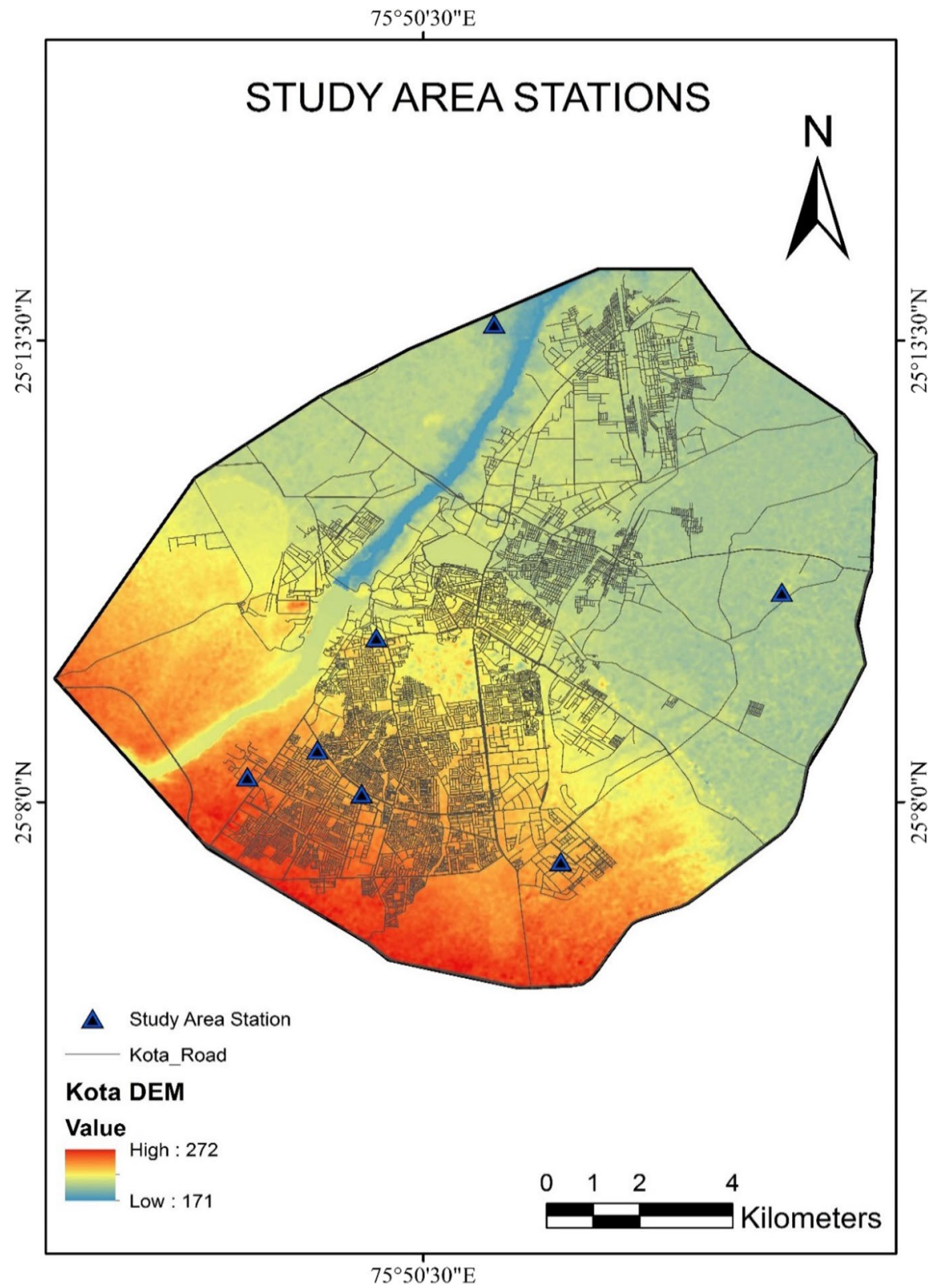

Table 3 Monitoring stations selected for interpolations

\begin{tabular}{lllll}
\hline S. no & Monitoring locations & Longitude (degrees) & Latitude (degrees) & Land use or major activity \\
\hline 1 & Municipal corporation building, Kota & 75.8325 & 25.1660 & Commercial \\
2 & RSPCB, regional office, Kota & 75.8682 & 25.1214 & Industrial/Transport \\
3 & Fire station, Shreenathpuram, Kota & 75.8297 & 25.1349 & Residential \\
4 & Shreenathpuram stadium, Kota & 75.8211 & 25.1436 & Residential \\
\hline
\end{tabular}


Table 4 Target stations selected for interpolations

\begin{tabular}{lllll}
\hline S. no & Target locations & Longitude (degrees) & Latitude (degrees) & $\begin{array}{c}\text { Land use } \\
\text { or major } \\
\text { activity }\end{array}$ \\
\hline 1 & Rajasthan Technical University, Kota & 75.8076 & 25.1383 & Institutional \\
2 & Sewage treatment plant, Balita, Kota & 75.8483 & 25.2273 & Residential \\
3 & Samcor Glass Limited, Kota & 75.9119 & 25.1757 & Commercial \\
\hline
\end{tabular}

techniques. The spatiotemporal analysis of various air pollutants helps identify the critical hotspot locations and makes informed decisions for mitigation efforts. The analysis helps to visualise the pollutants better and provide predicted values for unmonitored sites.

The methodology being employed in this study has a vast scope in the air pollution field because lowmiddle-income countries face locational/financial/ logistical problems when setting up new monitoring stations.

\subsection{Ordinary Kriging}

An unspecified site, given the variance structures and characterised means, is measured by ordinary kriging (OK), a geostatistical method for spatial interpolation (Banerjee et al. 2014). Universal kriging is different from ordinary kriging in the manner that it characterises the mean structure. Ordinary kriging consists of covariates in a regression framework to represent local variation, whilst a constant mean over space is assumed by ordinary kriging. The variogram is used to assess variance features denoting dependability spatially. The squared difference of measurements in contrast to distances between locations for sets of data points is applied by variogram. Three parameters of covariance, namely, range, nugget, and partial sill, are used to model the variogram. The nugget and partial sill specify the non-spatial and spatial variability, respectively. The existing spatial correlation on a specified distance is known as range (Kim et al. 2014). It emphasises the spatially correlated components and utilises the fitted semi-variogram for interpolation. When compared to other interpolation techniques, kriging proves to be superior. The weights assigned in interpolation for estimation could be used for all other data sets. Its estimation for any observation point is so accurate, hence termed as an exact interpolator. Equation 1 gives predicted values of $y_{0}$ as:

$y_{0}=\sum_{i=1}^{n} y_{x} Z_{x}$

where.

$y_{0}=$ value predicted at point 0 ,

$Z_{\mathrm{x}}=$ weight related to point $x$.

$y_{\mathrm{x}}=$ known value at a point $x$, and.

$n=$ total number of sample points.

\subsection{Inverse Distance Weighing}

Inverse distance weighing invariably involves the underlying assumption that places closer to each other will be more alike than those points that lie some distance apart. The points closest to the target location will be assigned a greater weight in IDW, and the variation in allocated weights is inversely proportional to ' $\mathrm{p}^{\text {th }}$ power of distance'. Here $p$ stands for the power function $(p)$, which is a positive real number. Points closest to the point to be interpolated will be significantly influenced by the greater values of $p$. The summation of the product of 'measured values' and 'allotted weights' for all locations is a predicted parameter of a target location.

Equation 2 is used in the inverse distance weighted interpolation method to predict values:

$\boldsymbol{y}_{0}=\frac{\sum_{i=1}^{n} \boldsymbol{y}_{i} \frac{1}{d_{i}^{p}}}{\sum_{i=1}^{n} \frac{1}{d_{i}^{p}}}$

where.

$y_{0}=$ value predicted for location 0 ,

$y_{\mathrm{i}}=$ values known for a location $i$,

$d_{\mathrm{i}}=$ the gap $\mathrm{b} / \mathrm{w}$ location $i$ and location 0 ,

$n=$ total number of samples points, and. 
$p=$ power function.

After an extensive literature review, for the present study, $p$ is taken to be 2 (Shukla et al. 2020).

\section{Results}

This section focuses on assessing seasonal and annual air quality (NO2, SO2, and PM10) and modelling air pollutant concentration $\left(\mathrm{NO}_{2}, \mathrm{SO}_{2}\right.$, and $\left.\mathrm{PM}_{10}\right)$.

\subsection{Assessment of Seasonal and Annual Air Quality $\left(\mathrm{NO}_{2}, \mathrm{SO}_{2}\right.$, and $\left.\mathrm{PM}_{10}\right)$}

The monitoring period selected for this study was one year from 1 January 2019 to 31 December 2019. Seasonal, and monthly mean for $\mathrm{NO}_{2}, \mathrm{SO}_{2}$, and $\mathrm{PM}_{10}$ for all monitoring stations are shown in Figs. 2, 3 , and 4, respectively. The AQI is calculated for all the monitoring stations, shown in Fig. 6.

\subsubsection{Seasonal and Annual Variation in the Concentration of $\mathrm{NO}_{2}$}

Figure 2 shows that the concentration of $\mathrm{NO}_{2}$ in the winter season lies between 22.71 and $51.51 \mu \mathrm{g} /$ $\mathrm{m}^{3}$. The maximum concentration $\left(51.51 \mu \mathrm{g} / \mathrm{m}^{3}\right)$ was observed at Shreenathpuram Stadium in December 2019. The minimal was observed $\left(22.71 \mu \mathrm{g} / \mathrm{m}^{3}\right)$ at the Samcor Glass Limited in the same month of 2019. The summer season concentration range of $\mathrm{NO}_{2}$ was found between 12.47 and $36.81 \mu \mathrm{g} / \mathrm{m}^{3}$. Shreenathpuram Stadium is the place where both higher concentrations $\left(36.81 \mu \mathrm{g} / \mathrm{m}^{3}\right)$ and lower concentrations $\left(12.47 \mu \mathrm{g} / \mathrm{m}^{3}\right)$ were observed in March 2019 and June 2019 , respectively.

In the rainy season, the concentration of $\mathrm{NO}_{2}$ was recorded in the range of 16.60 to $25.87 \mu \mathrm{g} / \mathrm{m}^{3}$. The minimum concentration of $\mathrm{NO}_{2}$ was $16.60 \mu \mathrm{g} / \mathrm{m}^{3}$ in September 2019, and the maximum concentration was $25.87 \mu \mathrm{g} / \mathrm{m}_{3}$ in October 2019. Both maximum and minimum values were observed at Shreenathpuram Stadium. On an annual basis, the range of $\mathrm{NO}_{2}$ is between 16.60 and $51.51 \mu \mathrm{g} / \mathrm{m}^{3}$. The highest concentration $\left(51.51 \mu \mathrm{g} / \mathrm{m}^{3}\right)$ was observed in December 2019 and the lowest concentration of $\mathrm{NO}_{2}$ was

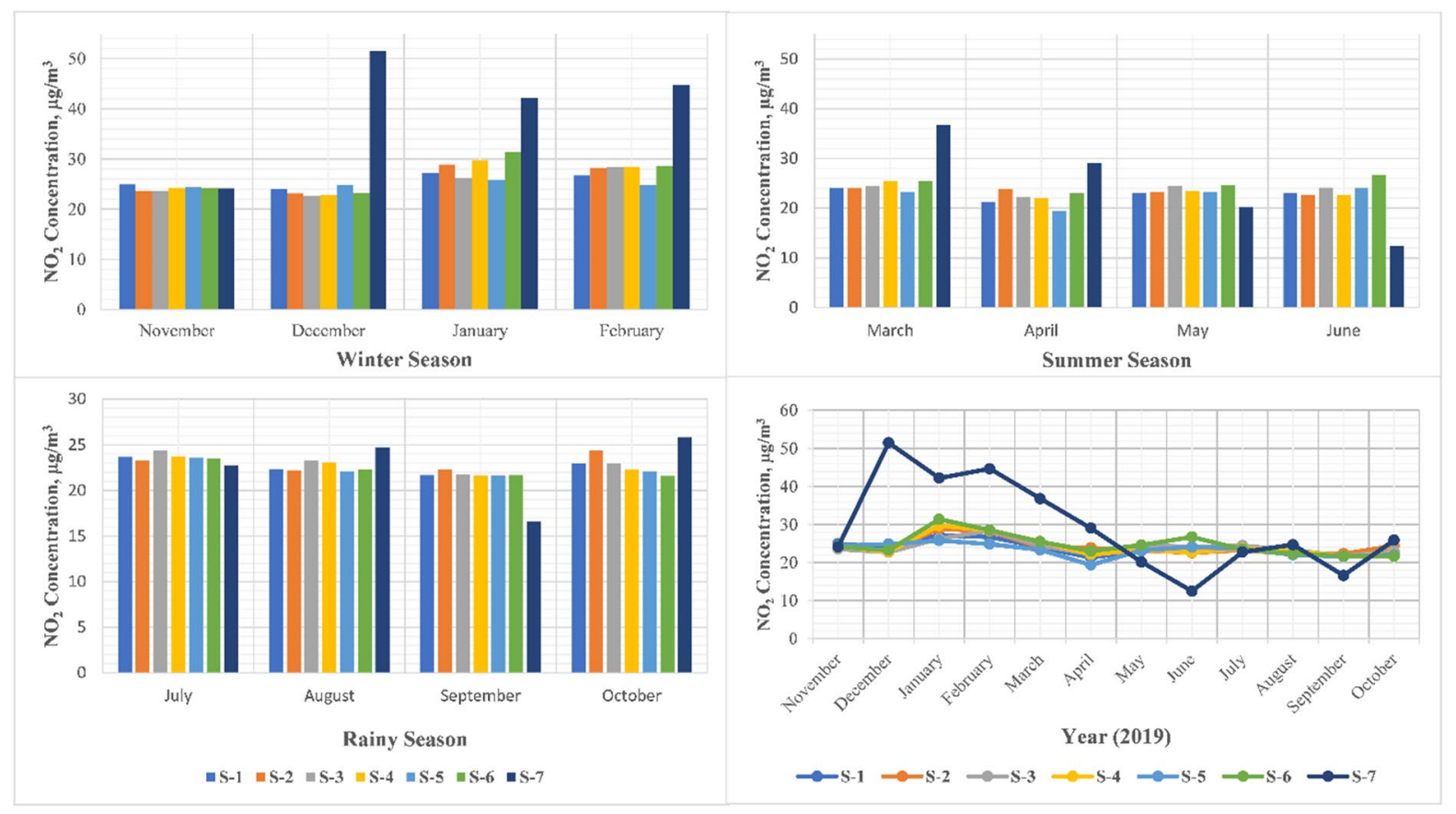

Fig. 2 The change in concentration of $\mathrm{NO}_{2}\left(\right.$ standard $\left.=80 \mu \mathrm{g} / \mathrm{m}^{3}\right)$ on seasonal and annual basis for all monitoring stations 

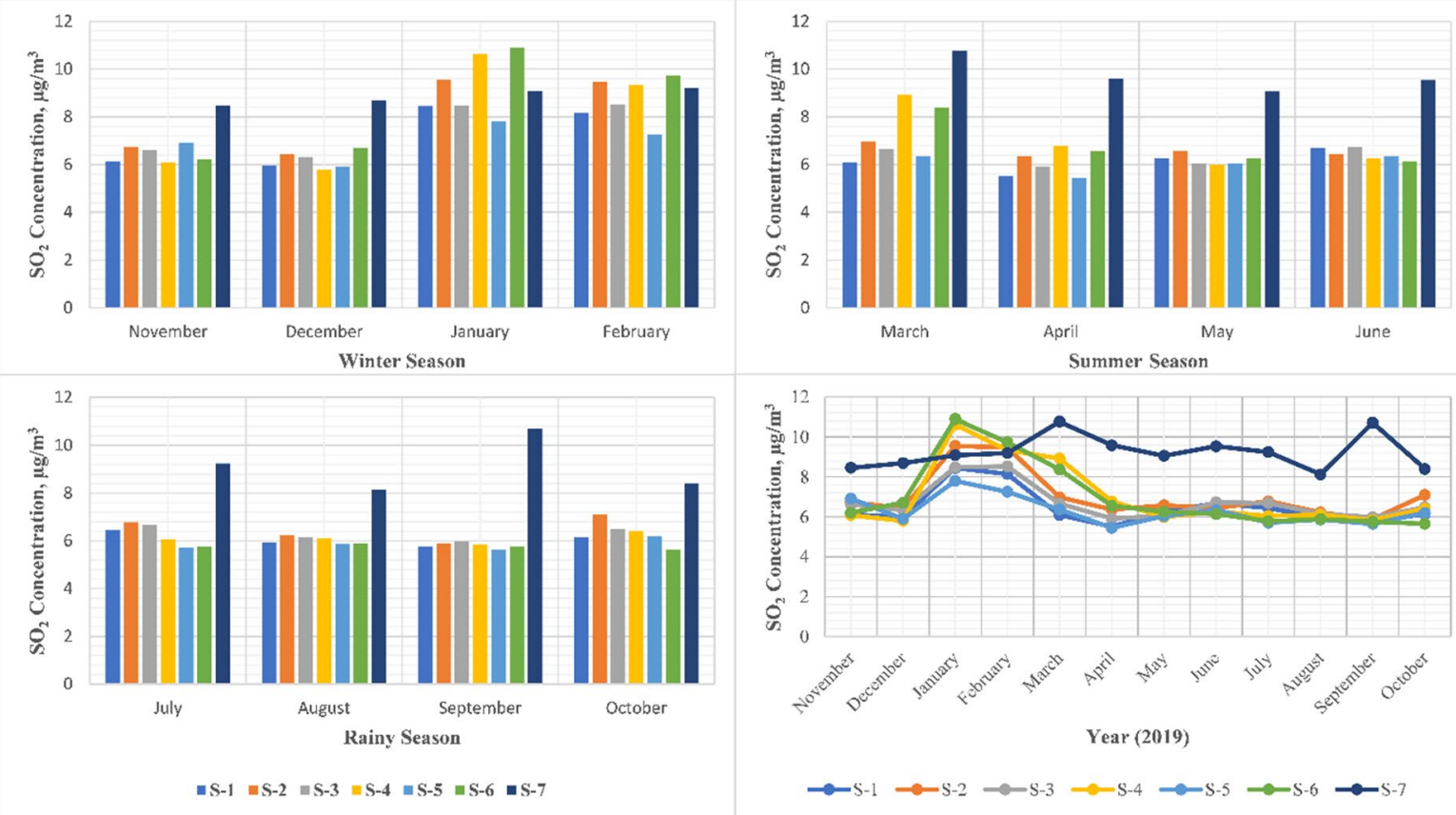

Fig. 3 The change in concentration of $\mathrm{SO}_{2}\left(\right.$ standard $=80 \mu \mathrm{g} / \mathrm{m}^{3}$ ) on seasonal and annual basis for all monitoring stations

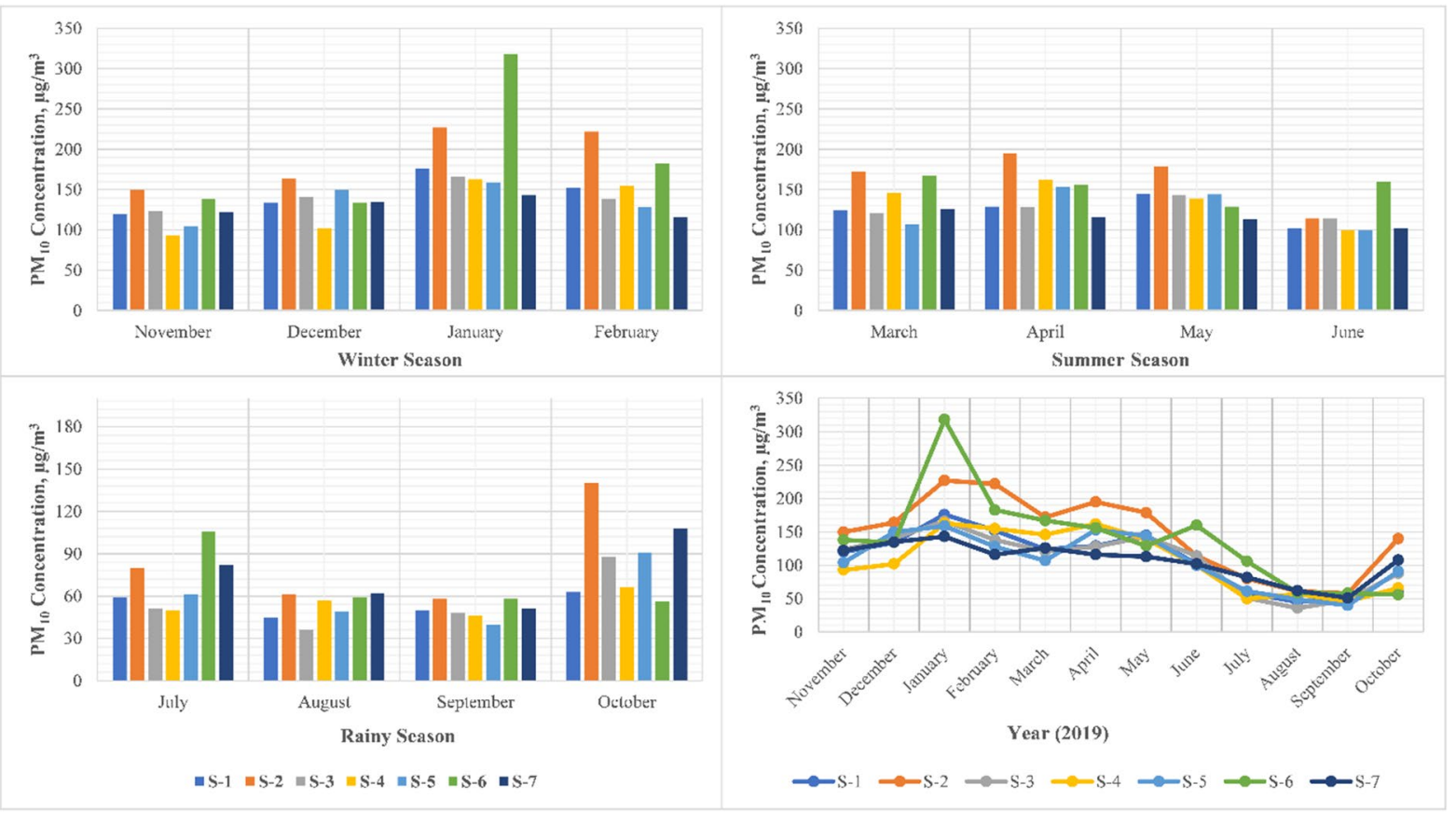

Fig. 4 The change in concentration of $\mathrm{PM}_{10}$ (standard $=100 \mu \mathrm{g} / \mathrm{m}^{3}$ ) on seasonal and annual basis for all monitoring station 
$16.60 \mu \mathrm{g} / \mathrm{m}^{3}$ in September 2019; both were at the same location (Shreenathpuram Stadium). The concentration of $\mathrm{NO}_{2}$ on seasonal and annual basis is within the standard limit given by the CPCB.

The changes in concentrations of $\mathrm{NO}_{2}$ can be attributed to meteorological conditions owing to seasonal changes. The reduction in $\mathrm{NO}_{2}$ concentration during precipitation may give rise to acid rains, especially with initial showers. For winters, wind speed becomes slow along with temperature inversion, which gives frequent spikes in the $\mathrm{NO}_{2}$ concentration. The lower temperature and reduced solar insolation values also tend to make longer $\mathrm{NO}_{2}$ lifetimes, leading to pollutant fluctuations during winters. Furthermore, the lower mixed layer height in colder days leads to the accumulation of pollutants.

\subsubsection{Seasonal and Annual Variation in the Concentration of $\mathrm{SO}_{2}$}

Figure 3 shows that the concentration of $\mathrm{SO}_{2}$ in winter lies between 5.80 and $10.89 \mu \mathrm{g} / \mathrm{m}^{3}$. The maximum concentration $\left(10.89 \mu \mathrm{g} / \mathrm{m}^{3}\right)$ was observed at Rajasthan Technical University in January 2019. The minimal was observed $\left(5.80 \mu \mathrm{g} / \mathrm{m}^{3}\right)$ at the Fire Station, Shreenathpuram, in December 2019. The summer season concentration range of $\mathrm{SO}_{2}$ was found in between 5.45 and $10.77 \mu \mathrm{g} / \mathrm{m}^{3}$. Shreenathpuram Stadium is the place where the higher concentration $\left(10.77 \mu \mathrm{g} / \mathrm{m}^{3}\right)$ was observed in March 2019, and the lower concentration $\left(5.45 \mu \mathrm{g} / \mathrm{m}^{3}\right)$ was observed at Sewage Treatment Plant Balita in April 2019.

In the rainy season, the concentration of $\mathrm{SO}_{2}$ was recorded in the range of 5.65 to $10.71 \mu \mathrm{g} / \mathrm{m}^{3}$. The minimum concentration of $\mathrm{SO}_{2}$ was $5.65 \mu \mathrm{g} / \mathrm{m}^{3}$ at Sewage Treatment Plant Balita in September 2019, and the maximum concentration was $10.71 \mu \mathrm{g} / \mathrm{m}^{3}$ at Rajasthan Technical University in September 2019. On an annual basis, the range of $\mathrm{SO}_{2}$ is between 5.45 and $10.89 \mu \mathrm{g} / \mathrm{m}^{3}$. The highest concentration $\left(10.89 \mu \mathrm{g} / \mathrm{m}^{3}\right)$ was observed at Rajasthan Technical University in January 2019, and the lowest concentration of $\mathrm{SO}_{2}$ was $5.45 \mu \mathrm{g} / \mathrm{m}^{3}$ at Sewage Treatment Plant Balita in April 2019. The concentration of $\mathrm{SO}_{2}$ on seasonal and annual basis is within the standard limit given by the CPCB.

The primary reason for $\mathrm{SO}_{2}$ may be attributed to the thermal power plant, which is being prominently used for energy generation purposes. Vehicular emissions along the major highways also play a significant role in its increase in overall concentrations. However, better emission control strategies and recent policy developments pertaining to emission norms have played a major role in reducing pollution to acceptable norms. The disparity in the meteorological conditions due to seasonal variations is attributed as a factor for fluctuations in pollutant concentrations.

\subsubsection{Seasonal and Annual Variation in the Concentration of $P M_{10}$}

Figure 4 shows that the concentration of $\mathrm{PM}_{10}$ in winter lies between 93 and $318 \mu \mathrm{g} / \mathrm{m}^{3}$. The maximum concentration $\left(318 \mu \mathrm{g} / \mathrm{m}^{3}\right)$ was observed at Rajasthan Technical University in January 2019. The minimal was observed $\left(93 \mu \mathrm{g} / \mathrm{m}^{3}\right)$ at the Fire Station Shreenathpuram in November 2019.

The summer season concentration range of $\mathrm{PM}_{10}$ was found in between 100 and $195 \mu \mathrm{g} / \mathrm{m}^{3}$. RSPCB Regional Office is the place where a higher concentration $\left(195 \mu \mathrm{g} / \mathrm{m}^{3}\right)$ was observed in April 2019 and lower concentration $\left(100 \mu \mathrm{g} / \mathrm{m}^{3}\right)$ was observed at two places: (i) Fire Station Shreenathpuram, and (ii) Sewage Treatment Plant Balita, in June 2019.

In the rainy season, the concentration of $\mathrm{PM}_{10}$ was recorded in the range of 36 to $140 \mu \mathrm{g} / \mathrm{m}^{3}$. The minimum concentration of $\mathrm{PM}_{10}$ was $36 \mu \mathrm{g} / \mathrm{m}^{3}$ at the Samcor Glass Limited in August 2019 and the maximum $\mathrm{PM}_{10}$ level was $140 \mu \mathrm{g} / \mathrm{m}^{3}$ at RSPCB Regional Office in October 2019.

On annual basis, the range of $\mathrm{PM}_{10}$ is between 36 and $318 \mu \mathrm{g} / \mathrm{m}^{3}$. The highest concentration $(318 \mu \mathrm{g} /$ $\mathrm{m}^{3}$ ) was observed at Rajasthan Technical University in January 2019, and the lowest concentration of $\mathrm{PM}_{10}$ was $36 \mu \mathrm{g} / \mathrm{m}^{3}$ at the Samcor Glass Limited in August 2019. The concentration of $\mathrm{PM}_{10}$ is crossing the standard limit in the winter and summer seasons.

Particulate matter concentration reduction is observed in the rainy season due to precipitation. Stone cutting industries, crushing industries, chemical and fertiliser plants, power plants, cement plant, municipal incineration, petrol and diesel stations, natural dust, agriculture burning, and increased vehicle population etc. are mainly responsible for the higher concentration of $\mathrm{PM}_{10}$ in the city. The winters in northern India are associated with low wind regimes, increasing the air pollution potential 
of the city. Woodstock burning for household heating coupled with lower wind speeds increases particulate matter concentrations during winters. Temperature inversion aids to vertical mixing of layers, thus accumulating the local and transported pollutants and escalating the pollution level with accumulated pollutant concentrations.

\subsubsection{Seasonal and Annual Variation in the AQI}

Figure 5 shows the variation in AQI throughout the year. The maximal AQI (268) was observed at Fire Station Shreenathpuram in January 2019. The minimal was observed (93) at the Rajasthan Technical University in November 2019. The summer season AQI was found in between 100 and 163. RSPCB Regional Office is the place where higher AQI (163) was observed in April 2019 and lower AQI $\left(100 \mu \mathrm{g} / \mathrm{m}^{3}\right)$ was observed at two places: (i) Fire Station Shreenathpuram, and (ii) Sewage Treatment Plant Balita, in June 2019. In the rainy season, the AQI was recorded in the range of 36 to 127 . The minimum AQI was 36 at the Samcor Glass Limited in August 2019 and the maximum noise level was 127 at the RSPCB Regional Office in the month of October 2019. On an annual basis, the range of AQI is between 36 and 268. The highest AQI (268) was observed at Fire Station Shreenathpuram in January 2019, and the lowest concentration of AQI was
36 at Samcor Glass Limited in August 2019. The AQI for the winter and summer season is observed between 100 and 200 (moderate category). Prolonged exposure in this AQI range leads to breathing discomfort, asthma, and lung and heart diseases. However, some reduction is observed during monsoon due to precipitation. The AQI in this season lies in between 50 and 100 (satisfactory category). Only sensitive people have minor breathing discomfort for this range of AQI.

\subsection{Modelling of Air Pollutants}

Predictions were made at three locations: Rajasthan Technical University; sewage treatment plant, Balita; and Samcor Glass Limited using $\mathrm{NO}_{2}, \mathrm{SO}_{2}$, and $\mathrm{PM}_{10}$ concentration data for each month from 1 January 2019 to 31 December 2019 from four monitoring stations (municipal corporation building, RSPCB regional office, fire station Shreenathpuram, and Shreenathpuram stadium). Both kriging and IDW predictions were achieved for all three sites and then plotted on the graphs with observed data, as shown in Fig. 6. Table 5 and Table 6 are used to present monitoring and target stations, respectively.

The observed trends from monitored and predicted values are pretty similar except for the variation in magnitude. Figure 7a, b, and c show the predicted surfaces of $\mathrm{NO}_{2}$ concentration for winter, summer, and
Fig. 5 Monthly changes in air quality index for Kota city in year 2019

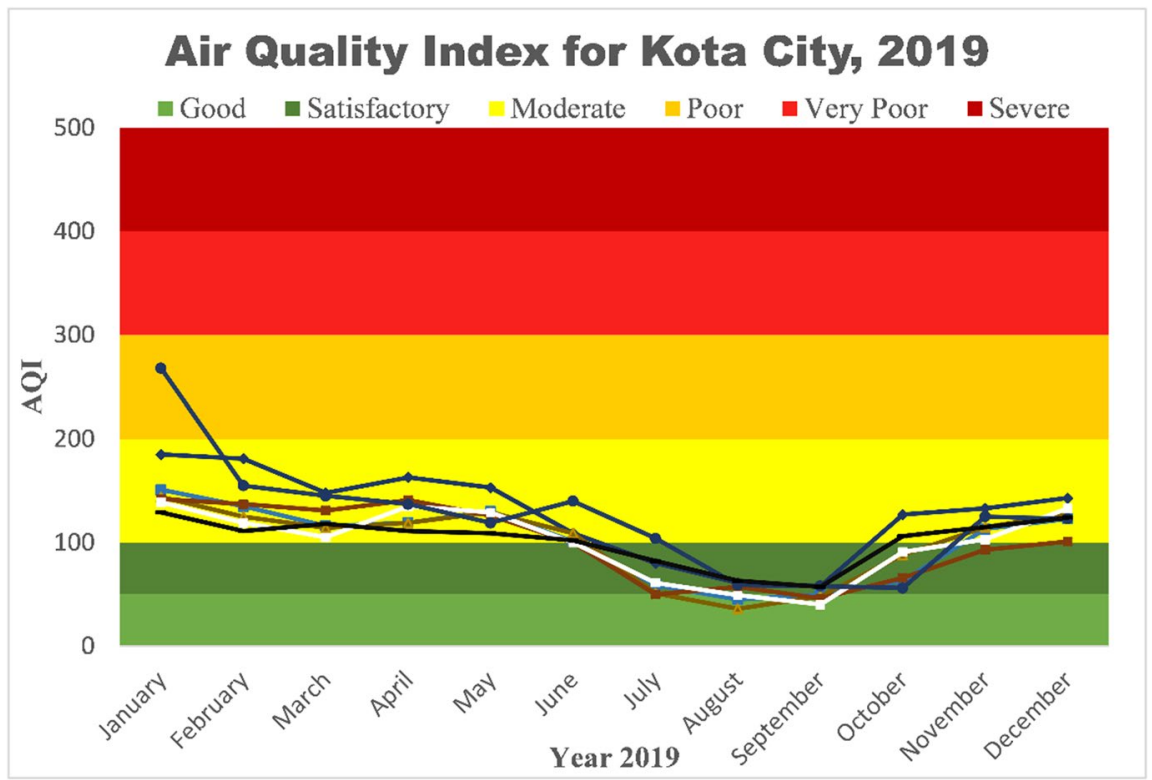




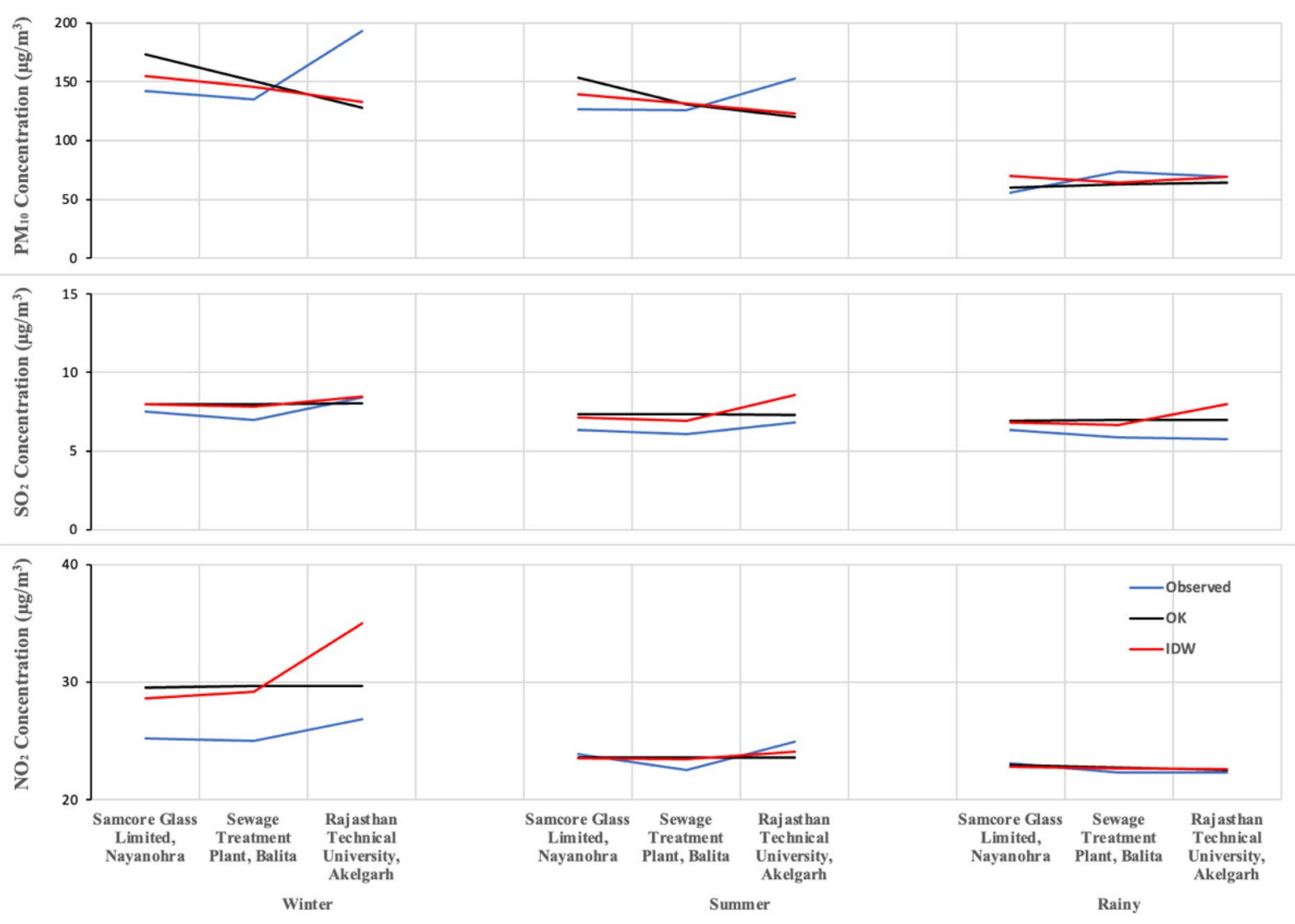

Fig. 6 Observed and predicted concentrations for target location

Table 5 Monitoring stations selected for $\mathrm{OK}$ and IDW interpolations

\begin{tabular}{llll}
\hline S. no & Monitoring locations & Longitude (degrees) & Latitude (degrees) \\
\hline 1 & Municipal corporation building, Kota & 75.8325 & 25.1660 \\
2 & RSPCB, regional office, Kota & 75.8682 & 25.1214 \\
3 & Fire station, Shreenathpuram, Kota & 75.8297 & 25.1349 \\
4 & Shreenathpuram Stadium, Kota & 75.8211 & 25.1436 \\
\hline
\end{tabular}

Table 6 Targeted stations selected for OK and IDW interpolations

\begin{tabular}{llll}
\hline S. no & Targeted locations & Longitude (degrees) & Latitude (degrees) \\
\hline 1 & Rajasthan Technical University, Kota & 75.8076 & 25.1383 \\
2 & Sewage Treatment Plant, Balita, Kota & 75.8483 & 25.2273 \\
3 & Samcor Glass Limited, Kota & 75.9119 & 25.1757 \\
\hline
\end{tabular}

rainy seasons, respectively, by $\mathrm{OK}$. Figure 7d, e, and $f$ show the predicted surfaces of $\mathrm{NO}_{2}$ concentration for winter, summer, and rainy seasons, respectively, by IDW. Obtained results suggest that 12 month $\mathrm{NO}_{2}$ concentrations exhibit errors of the magnitude as 31 and 24\% for winter; 4 and 2\% for summer; and 1 and $1 \%$ for rainy, with IDW and OK, respectively. This indicates that OK performs better with the observed datasets; meteorological variability contributes to the 


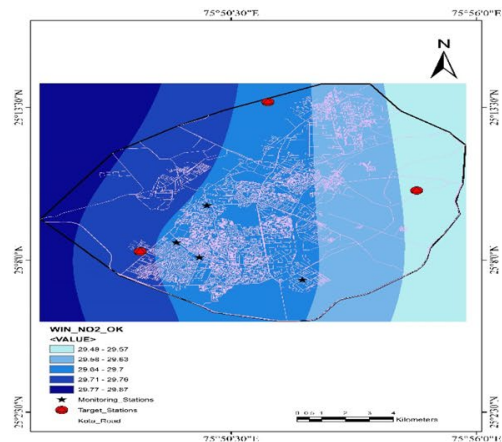

(a) Winter season concentration of $\mathrm{NO}_{2}(\mathrm{OK})$

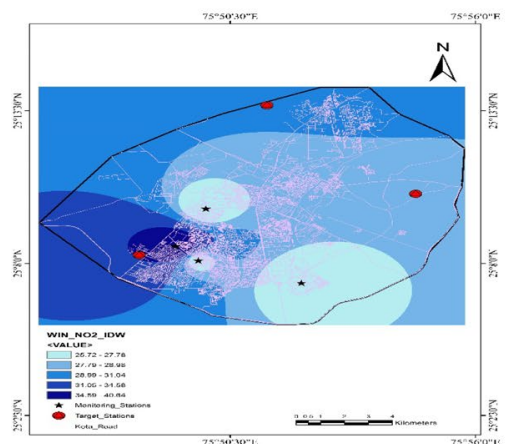

(d) Winter season concentration of $\mathrm{NO}_{2}$ (IDW)

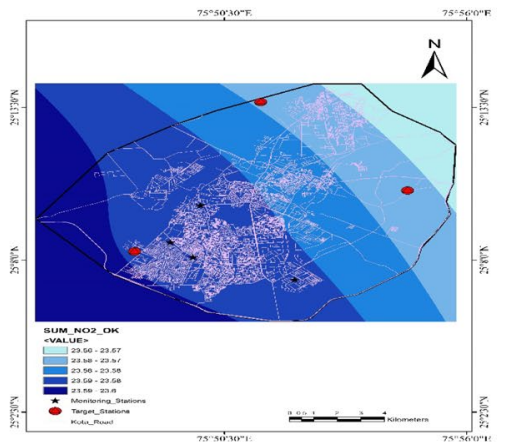

(b) Summer season concentration of $\mathrm{NO}_{2}(\mathrm{OK})$

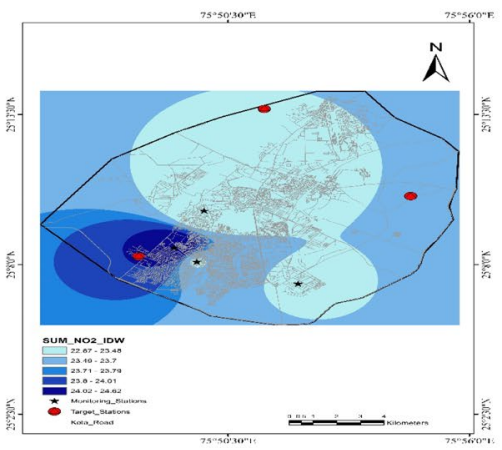

(e) Summer season concentration of $\mathrm{NO}_{2}$ (IDW)

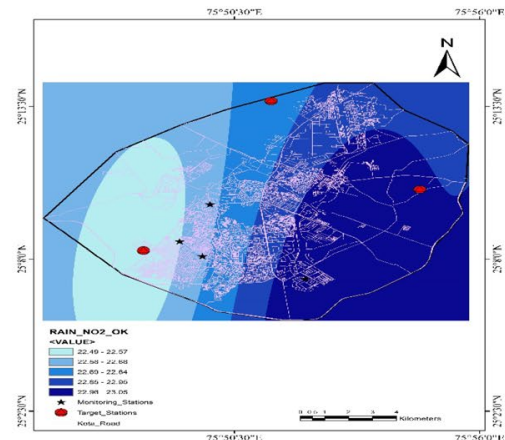

(c) Rainy season concentration of $\mathrm{NO}_{2}(\mathrm{OK})$

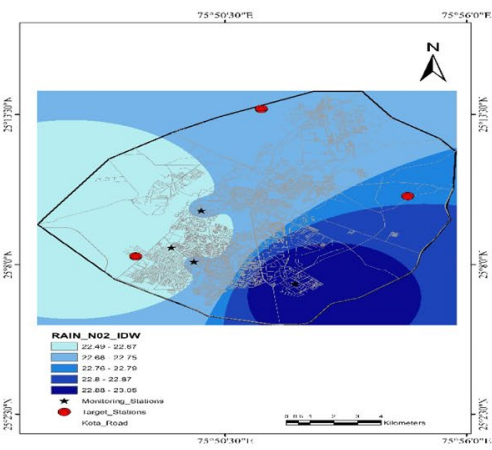

(f) Rainy season concentration of $\mathrm{NO}_{2}$ (IDW)

Fig. 7 OK-predicted surfaces for $\mathrm{NO}_{2}$ in a winter, b summer, and $\mathbf{c}$ rainy; IDW-predicted surfaces for $\mathrm{NO}_{2}$ in $\mathbf{d}$ winter, e summer, and $\mathbf{f}$ rainy

observed trends which are quite evident from winter results.

Figures $8 \mathrm{a}, \mathrm{b}$, and $\mathrm{c}$ show the predicted surfaces of $\mathrm{SO}_{2}$ concentration for winter, summer, and rainy seasons, respectively, by OK. Figure 8d, e, and f show the predicted surfaces of $\mathrm{SO}_{2}$ concentration for winter, summer, and rainy seasons, respectively, by IDW. Obtained results suggest that 12 month $\mathrm{SO}_{2}$ concentrations exhibit errors of magnitude as 30 and $25 \%$ for winter; 4 and $3 \%$ for summer; and 1 and $1 \%$ for rainy, for IDW and OK, respectively. As observed $\mathrm{SO}_{2}$ concentrations do not fluctuate much, IDW gives better representations of spatial patterns and is more consistent with observed datasets when compared to OK. Low concentrations coupled with less spatial fluctuations tend to make OK generating smooth surfaces which make spatial distinction difficult.

Figure 9a, b, and c show the predicted surfaces of $\mathrm{PM}_{10}$ concentration for winter, summer, and rainy seasons, respectively, by OK. Figure 9d, e, and f show the predicted surfaces of $\mathrm{PM}_{10}$ concentration for winter, summer, and rainy seasons respectively by IDW. Obtained results suggest that 12 month $\mathrm{PM}_{10}$ concentrations exhibit errors of magnitude as 23 and $22 \%$ for winter; 14 and $12 \%$ for summer; and 16 and $12 \%$ for rainy, for IDW and OK, respectively. As particulate matter concentrations fluctuate spatially as well as on a temporal scale, establishing trends and sustaining them across the seasons make it difficult unless strong correlations are established with meteorological parameters. As wind speeds and directions play a major role in the dispersion of pollutants, these influencing factors indirectly affect distribution factors (Qiao et al. 2018). However, as the spatial distribution of the interpolation results is consistent with the observed monitoring data, this makes the interpolation results quite reliable.

The variation in percentage error is subjected to target locations for which values are required to be computed. Larger effective distances between the locations due to larger grid sizes lead to higher errors in predictions. High-resolution case studies provide 


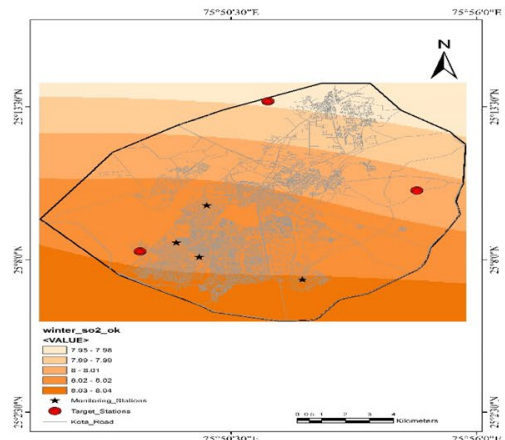

(a) Winter season concentration of $\mathrm{SO}_{2}(\mathrm{OK})$

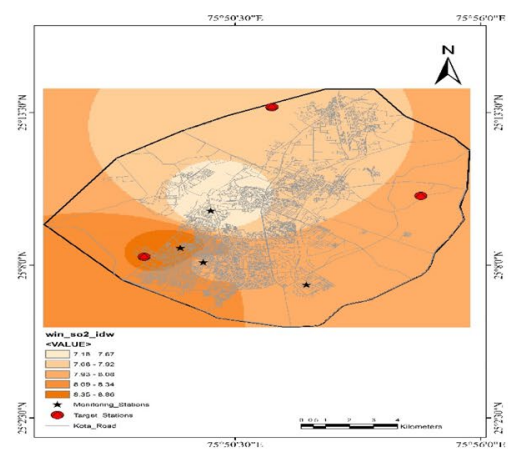

(d) Winter season concentration of $\mathrm{SO}_{2}$ (IDW)

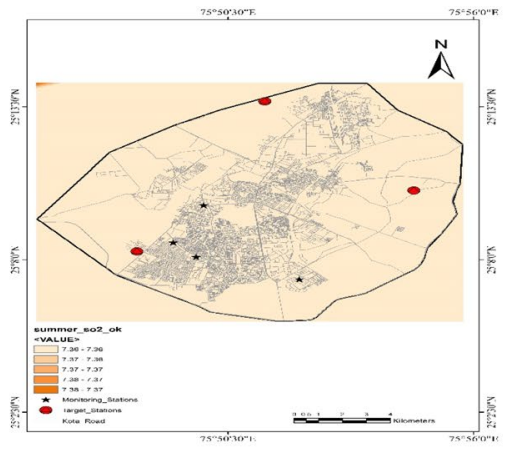

(b) Summer season concentration of $\mathrm{SO}_{2}(\mathrm{OK})$

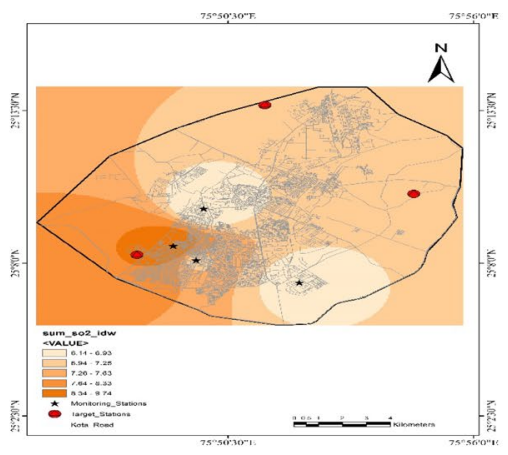

(e) Summer season concentration of $\mathrm{SO}_{2}$ (IDW)

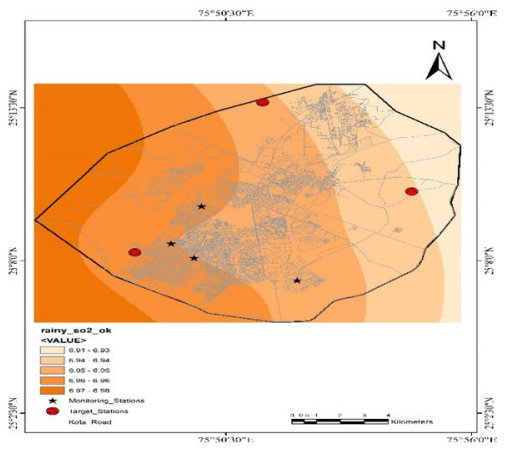

(c) Rainy season concentration of $\mathrm{SO}_{2}(\mathrm{OK})$

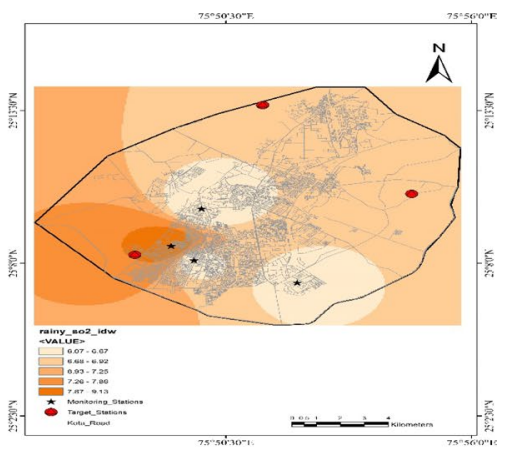

(f) Rainy season concentration of $\mathrm{SO}_{2}$ (IDW)

Fig. 8 OK-predicted surfaces for $\mathrm{SO}_{2}$ in a winter, b summer, and $\mathbf{c}$ rainy; IDW-predicted surfaces for $\mathrm{SO}_{2}$ in $\mathbf{d}$ winter, e summer, and $\mathbf{f}$ rainy

more accurate results regarding the effective distance between the locations and the variation in concentration of pollutants for more precise forecasting. Also, different techniques have given variable results for the same datasets, which makes studying multiple techniques a necessity (Qiao et al. 2018; Shukla et al. 2020; Yu et al. 2018).

Kriging and IDW interpolation techniques are used to predict the pollutant concentration worldwide with acceptable dependability, and its use with other spatial interpolation methods has a wide scope (Alexeeff et al. 2015; Shukla et al. 2020). The reliability of prediction will significantly improve if metrological and physical factors are considered in raw prediction. Kriging can be used for scattered monitoring locations because it does not have any grid, making it versatile (Qi et al. 2018; Shukla et al. 2020; Yu et al. 2018).

\section{Discussion}

Studies have been conducted which compare multiple pollutants and various techniques(Yu et al. 2018). A recent study over Shanghai, China, for $\mathrm{PM}_{10}$ and $\mathrm{PM}_{2.5}$ states that $\mathrm{PM}_{2.5}$ was better suited with IDW and kriging with $\mathrm{PM}_{10}$ (Qi et al. 2018). Several studies also indicate that a substantial increase in the geographical area gives ambiguous results, with an increase in distance between monitoring and target stations causing significant errors amongst the results. They also cause significant inaccuracy with results resulting from predictions (Xu et al. 2019). The study indicates that distance is an inverse function of reliability when analysis of errors is carried out for predicted results.

Studies for Madrid, Spain (Gómez-Losada et al. 2019), indicated that Urban Heat Islands also influence predicted values for pollutants. In recent years, Kota has also experienced urban heat island effect across densely populated areas (Panwar et al. 2021). 


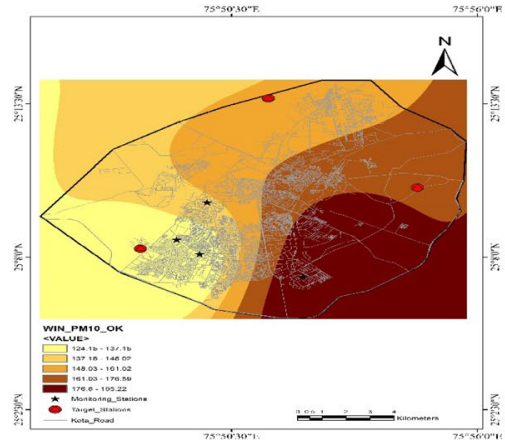

(a) Winter season concentration of $\mathrm{PM}_{10}(\mathrm{OK})$

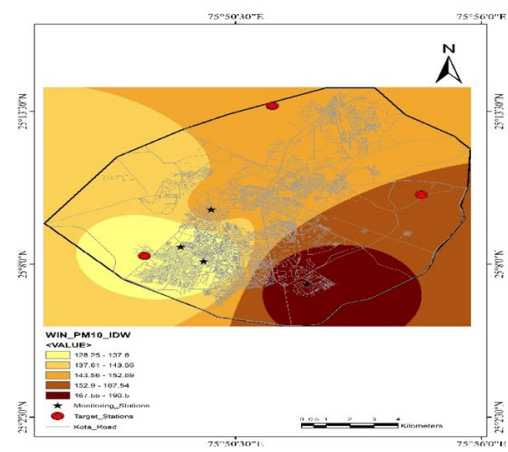

(d) Winter season concentration of $\mathrm{PM}_{10}$ (IDW)

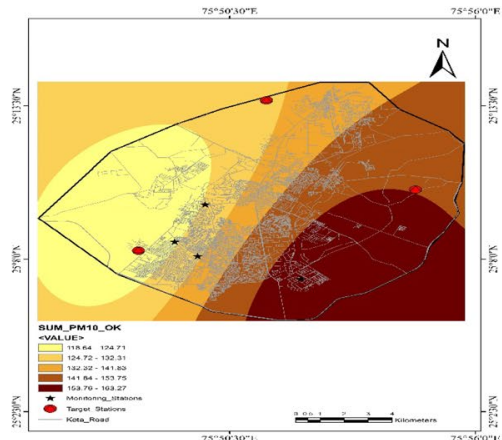

(b) Summer season concentration of $\mathrm{PM}_{10}(\mathrm{OK})$

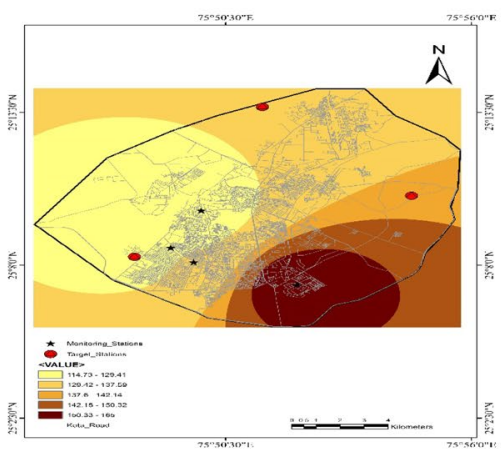

(e) Summer season concentration of $\mathrm{PM}_{10}$ (IDW)

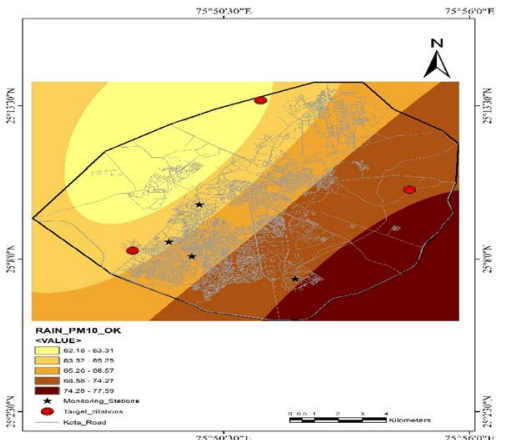

(c) Rainy season concentration of $\mathrm{PM}_{10}(\mathrm{OK})$

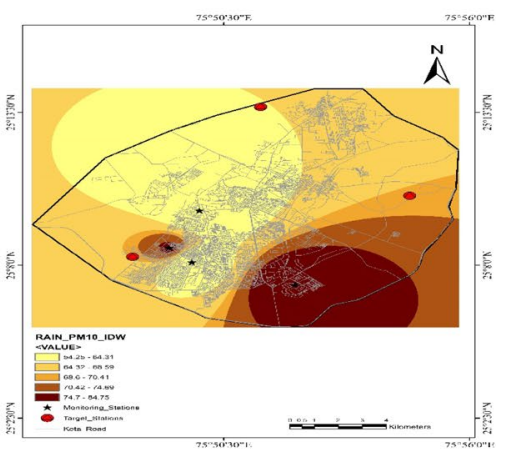

(f) Rainy season concentration of $\mathrm{PM}_{10}$ (IDW)

Fig. 9 OK-predicted surfaces for $\mathrm{PM}_{10}$ in a winter, b summer, and c rainy; IDW-predicted surfaces $\left(\mathrm{PM}_{10}\right)$ in $\mathbf{d}$ winter, e summer, and $\mathbf{f}$ rainy

Additionally, some studies conducted for the Kocaeli region in Turkey indicate that wind speed and its orientation also affect results and their corresponding predicted values (Erener et al. 2019).

The first part of this study focused on the evolution of the air quality in Kota city. Seven important locations were selected for air monitoring. This study revealed that the concentrations of sulphur dioxide $\left(\mathrm{SO}_{2}\right)$ and nitrogen dioxide $\left(\mathrm{NO}_{2}\right)$ were well below the CPCB standards for both annual and seasonal basis. And the concentration of particulate matter $\left(\mathrm{PM}_{10}\right)$ reached an alarming level in the city. It was observed that the concentration of $\mathrm{PM}_{10}$ at all locations exceeded the national standards set by the CPCB in the winter and summer seasons. Its concentration was below the standards only in the rainy season (Sisodiya et al. 2021). The leading causes of higher concentration of $\mathrm{PM}_{10}$ were stone cutting industries, crushing industries, chemical and fertiliser plants, power plants, cement plants, municipal incineration, petrol and diesel stations, natural dust, agriculture burning, and increased vehicle population, etc. The range of AQI was between 36 and 268. The concentration of pollutant $\mathrm{PM}_{10}$ greatly influenced the AQI of Kota city.

The second part of this study focused on developing OK and IDW based models for the prediction of air pollutant concentration. The observed concentration of $\mathrm{SO}_{2}, \mathrm{NO}_{2}$, and $\mathrm{PM}_{10}$ from four monitoring stations located at different places of the city is used in this study to predict the corresponding values at the three locations of interest in the metropolis. Cross-validation analysis concluded that 12-month $\mathrm{NO}_{2}$ concentrations exhibit large errors ( 31\%) majorly during winters and least for rainy seasons. A similar trend is observed with $\mathrm{SO}_{2}$ concentrations exhibiting errors of magnitude as 30 and 25\% for winter, and $1 \%$ for rainy, for IDW and kriging, respectively. As the pollutant concentrations vary spatially for $\mathrm{PM}_{10}$ concentrations, it exhibited errors of magnitude as 23 and $22 \%$ for winter; 14 and $12 \%$ 
for summer; and $16 \%$ and $12 \%$ for rainy, for IDW and ordinary kriging, respectively.

Results obtained from both IDW and ordinary kriging showed similar trends for winter, summer, and rainy seasons. Cross-validation error percentage was also within the acceptable limits. Thus, it is pretty challenging and difficult to make out the best from both methods; however, when it comes to interpolation owing to data stationarity, IDW performs better.

\section{Conclusions}

The interpolation accuracies for OK and IDW were found to be in strong correlation with spatial correlations for pollutant concentrations. The predictions shall improve significantly with areas of higher spatial correlations and weaker spatial variability. The cross-validation results decrease with the increase in spatial correlations. When the meteorological variability is less variable, the prediction results are consistent with real spatial variability.

When the spatial distribution of pollutant concentrations shows high variability, the intersection of high concentration areas with low concentration areas in space, the high pollution areas were identified by IDW in a better way. However, in areas with high concentrations of pollutants concentrated in a few regions, the identification accuracies of both methods are quite similar.

Mapping methods used in this study would help in the identification of hotspots located across the city, and accordingly, data-driven-based mitigation measures can be planned as these kinds of cities are growing at an appreciable rate with regard to population along with road traffic, thereby increasing demand for energy. The mapped profiles for air pollutants will greatly help future town planning, which shall concur with monitored data.

Acknowledgements The authors would like to thank Ms. Namrata Chidambar for her assistance in proof reading the manuscript.

Funding Open Access funding enabled and organized by CAUL and its Member Institutions.

Data Availability The datasets of this study may be available from the corresponding author on request.

\section{Declarations}

Conflict of Interest The authors declare no competing interests.

Open Access This article is licensed under a Creative Commons Attribution 4.0 International License, which permits use, sharing, adaptation, distribution and reproduction in any medium or format, as long as you give appropriate credit to the original author(s) and the source, provide a link to the Creative Commons licence, and indicate if changes were made. The images or other third party material in this article are included in the article's Creative Commons licence, unless indicated otherwise in a credit line to the material. If material is not included in the article's Creative Commons licence and your intended use is not permitted by statutory regulation or exceeds the permitted use, you will need to obtain permission directly from the copyright holder. To view a copy of this licence, visit http://creativecommons.org/licenses/by/4.0/.

\section{References}

Abernethy, R. C., Allen, R. W., McKendry, I. G., \& Brauer, M. (2013). A land use regression model for ultrafine particles in Vancouver. Canada. Environ Sci Technol, 47, 5217-5225.

Alexeeff, S. E., Schwartz, J., Kloog, I., Chudnovsky, A., Koutrakis, P., \& Coull, B. A. (2015). Consequences of kriging and land use regression for PM2.5 predictions in epidemiologic analyses: Insights into spatial variability using high-resolution satellite data. J Expo Sci Environ Epidemiol, 25, 138-44.

Alvarez-Mendoza CI, Teodoro AC, Torres N, Vivanco V. Assessment of remote sensing data to model PM10 estimation in cities with a low number of air quality stations: A case of study in Quito, Ecuador. Environ - MDPI 2019;6.

Banerjee S, Carlin BP, Gelfand AE. Hierarchical modeling and analysis for spatial data. CRC press; 2014.

Batterman S, Jia C, Hatzivasilis G. Migration of volatile organic compounds from attached garages to residences : A major exposure source 2007;104:224-40.

Bosco ML, Varrica D, Dongarra G. Case study : Inorganic pollutants associated with particulate matter from an area near a petrochemical plant 2005;99:18-30.

Emami, F., Masiol, M., \& Hopke, P. K. (2018). Air pollution at Rochester, NY: Long-term trends and multivariate analysis of upwind SO2 source impacts. Sci Total Environ, 612, 1506-1515.

Erener A, Sarp G, Yıldırım Ö. Seasonal air pollution investigation and relation analysis of air pollution parameters to meteorological data (Kocaeli/Turkey) 2019:355-8.

Farrell, W. J., Deville, L., Weichenthal, S., Goldberg, M., \& Hatzopoulou, M. (2015). Capturing the urban canyon effect on particle number concentrations across a large road network using spatial analysis tools. Building and Environment, 92, 328-334. 
Forest Survey Reports. (2020). Forest Survey of India (FSI). Ministry of Environment \& Forests, Government of India :https://fsi.nic.in/. Accessed 3 Dec 2020.

Gómez-Losada, Á., Santos, F. M., Gibert, K., \& Pires, J. C. M. (2019). A data science approach for spatiotemporal modelling of low and resident air pollution in Madrid (Spain): Implications for epidemiological studies. Computers, Environment and Urban Systems, 75, 1-11.

Indian Census. (2011). District Census Reports Kota, Government of Rajasthan, India. https://censusindia.gov.in/2011c ensus/dchb/0829_PART_B_DCHB_KOTA.pdf.

Kim, S.-Y., Yi, S.-J., Eum, Y. S., Choi, H.-J., Shin, H., Ryou, H. G., \& Kim, H. (2014). Ordinary kriging approach to predicting long-term particulate matter concentrations in seven major Korean cities. Environ Health Toxicol, 29, e2014012.

Kuldeep, Sisodiya S, Mathur AK, Verma P. Assessment of urban air quality for Jodhpur city by the air quality index (AQI) and exceedance factor (EF). Adv. Mater. Manuf. Energy Eng. Vol. I, Singapore: Springer Singapore; 2022, p. 585-96.

Marć, M., Bielawska, M., Simeonov, V., Namieśnik, J., \& Zabiegała, B. (2016). The effect of anthropogenic activity on BTEX, NO2, SO2, and $\mathrm{CO}$ concentrations in urban air of the spa city of Sopot and medium-industrialized city of Tczew located in North Poland. Environ Res, 147, 513-524.

Othman, N., Mat Jafri, M. Z., \& San, L. H. (2010). Estimating particulate matter concentration over arid region using satellite remote sensing: A case study in Makkah. Saudi Arabia. Mod Appl Sci, 4, 131-142.

Panwar P., Sisodiya S., Mathur A. (2021) Two Decades of Urban Growth in Kota City: The Urban Heat Island Study. In: Baredar P.V., Tangellapalli S., Solanki C.S. (eds) Advances in clean energy technologies. Springer Proceedings in Energy. Springer, Singapore. https://doi.org/10. 1007/978-981-16-0235-1_79.

Pathakoti, M., et al. (2021). Measurement report: An assessment of the impact of a nationwide lockdown on air pollution - A remote sensing perspective over India. Atmospheric Chemistry and Physics, 21(11), 9047-9064. https:// doi.org/10.5194/acp-21-9047-2021

Qi, Z., Wang, T., Song, G., Hu, W., Li, X., \& Zhang, Z. (2018). Deep air learning: Interpolation, prediction, and feature analysis of fine-grained air quality. IEEE Transactions on Knowledge and Data Engineering, 30, 2285-2297.

Qiao, P., Lei, M., Yang, S., Yang, J., Guo, G., \& Zhou, X. (2018). Comparing ordinary kriging and inverse distance weighting for soil as pollution in Beijing. Environ Sci Pollut Res, 25, 15597-15608.

Region \& City PM2.5 Ranking, World Air Quality 2019, World Air Quality Report 2019:1-22, https://www.green peace.org/static/planet4-thailand-stateless/2020/02/91ab3 4b8-2019-world-air-report.pdf.

Region \& City PM2.5 Ranking, World Air Quality 2020, World Air Quality Report, 2020. https://www.bing.com/ search?q=world+air+quality+report+2020+pdf\&cvid= de2af80f67114905a40b4b1c0192397e\&aqs=edge.0.0. 9406j0j1\&pglt=43\&FORM=ANNTA1\&PC $=\mathrm{U} 531$.

Rivera, M., Basagaña, X., Aguilera, I., Agis, D., Bouso, L., Foraster, M., Medina-ramón, M., Pey, J., Künzli, N., \& Hoek, G. (2012). Spatial distribution of ultra fi ne particles in urban settings: A land use regression model. Atmospheric Environment, 54, 657-666.

Shukla, K., Kumar, P., Mann, G. S., \& Khare, M. (2020). Mapping spatial distribution of particulate matter using kriging and inverse distance weighting at supersites of megacity Delhi. Sustain Cities Soc, 54, 101997.

Sisodiya S, Kuldeep K, Mathur AK, Verma P. Assessment of particulate matter changes in large cities of Rajasthan (India) during COVID-19 lockdowns 2021, Paper ID: 36, https://www.casanz.org.au/casanz2021/casanz-2021-confe rence-proceedings/.

Wu, J., Wilhelm, M., Chung, J., \& Ritz, B. (2011). Comparing exposure assessment methods for traffic-related air pollution in an adverse pregnancy outcome study \$. Environ Res, 111, 685-692.

Xu, H., Bechle, M. J., Wang, M., Szpiro, A. A., Vedal, S., Bai, Y., \& Marshall, J. D. (2019). National PM2.5 and NO2 exposure models for China based on land use regression, satellite measurements, and universal kriging. Sci Total Environ, 655, 423-33.

Yu, H., Russell, A., Mulholland, J., Odman, T., Hu, Y., Chang, H. H., \& Kumar, N. (2018). Cross-comparison and evaluation of air pollution field estimation methods. Atmospheric Environment, 179, 49-60.

Publisher's Note Springer Nature remains neutral with regard to jurisdictional claims in published maps and institutional affiliations. 